\title{
SUSCEPTBILITY OF SOME COWPEA SEED VARIETIES TO TWO STORAGE BRUCHIDS INFESTATION
}

\author{
MOHAMED, E. M. ${ }^{1}$; A. E. ABDELMONEM ${ }^{2}$; \\ M. S. A. GHARIB ${ }^{1}$ and S. F. HAFEZ ${ }^{2}$ \\ 1. Plant Protection Research Institute, Agric. Res. Center, Giza, Egypt. \\ 2. Faculty of Agriculture, Azhar Univers.ity, Cairo, Egypt.
}

(Manuscript received 11 November 2018)

\begin{abstract}
$\mathrm{S}$ eeds of five cowpea varieties (Dokki331, Tiba, Kaha1, Kafr El-Sheikh and Cream7) were screened for there infestation by two storage bruchids named Callosobruchus maculatus (F.) and C. chinensis (L.) under free- choice and non free-choice methods. The mean number of eggs, the mean developmental period (MDP), the progeny number, the susceptibility index, weight loss (\%), damaged seeds (\%) and seeds germination (\%) are parameters of the evaluation. Results indicated that all cowpea varieties were attacked by both insects. Tiba and Dokki331 were more susceptible, while, the rest varieties were less susceptible. Dokki331 was highly susceptible to infestation by $C$. maculatus under free and non-free choice methods. It suffered a higher value of direct weight loss and damage. Cream7 and Kaha1 were partially resistant to both insects. None of the tested varieties were completely tolerant to infestation by the two test insects.
\end{abstract}

\section{INTRODUCTION}

Cowpea seeds are major human food and stored after harvest for the subsequent use or for trading the product (Augustine et al., 2016). Out of total 12.6 million tons, $8.5 \%$ is lost annually due to the non-proper storage facilities with the farmers and the infestation by storage pest insects (Goutam et al., 2016).

The cowpea beetle, Callosobruchus maculatus infests dry pulses as cowpea and broadbean by laying its eggs on outer surface of the ripe pods in the seeds. As the eggs hatch, the larvae feed on the contents of the seeds, pupate and transform to adults within the seeds. Adults go out from the infested seeds and are ready to mate and oviposit eggs. The growth time of the beetle is nearly three weeks depending on the available temperature and seed moisture variety (Boeke et al., 2004).

C. maculatus and C. chinensis are two serious storage bruchids which infest all pulse seeds as cowpea and broadbean and cause over $90 \%$ of damage to cowpea seeds (Caswell, 1981).

The infested cowpea seed suffer from losses and becomes unfit for human beings and also has a lower market value. Weight losses reach $60 \%$ as well as the holes on the infested seeds of cowpea and broadbean renders it unattractive and 
unpalatable, with greatly reduced market value and germinability (Chakraborty et al., 2015).

The present study was directed to evaluate many new promising cowpea varieties for infestation by two storage bruchids named $C$. maculatus and $C$. chinensis under the free choice and non- free choice methods for minimizing and reducing storage losses (Shaheen et al., 2006) and explaining the values of susceptibility index with the physical and the chemical characteristics.

\section{MATERIALS AND METHODS}

\section{Source of seed varieties:}

Five cowpea seed varieties i.e. Dokki331, Tiba, Kaha1, Kafr El-Sheikh and Cream7 were obtained from the Horticulture Research Institute, Agriculture Research Center (ARC), Dokki, Egypt. The seeds were sterilized by freezing at $-20^{\circ} \mathrm{C}$ for two weeks for killing any hidden insect stages. Samples of $500 \mathrm{~g}$ seeds of each variety was kept inside an incubator (Velp Scientifica type) at $28 \pm 1^{\circ} \mathrm{C}$ and $60 \pm 5 \%$ R.H., for two weeks to be acclimatized before testing.

\section{Insects cultures:-}

Cultures of Callosobruchus maculatus (F.) and C. chinensis (L.) were reared on a commercial cowpea seeds at $28 \pm 1^{\circ} \mathrm{C}$ and $60 \pm 5 \%$ R.H., in the Stored Grain Pest Department, Plant Protection Research Institute (PPRI), ARC, Dokki, Egypt. Adults of each species were reared separately in small glass jars covered with double cloth layer and firmly fixed with rubber bands to prevent the adults escape and kept at the previous conditions for mating and oviposition. Adults of both insects were removed after a week. Emergened adults were checked daily with separately the progeny for the experimental purposes.

\section{Susceptibility determination:}

Two methods named free- choice and non free- choice methods were used for determining the susceptibility index of the tested varieties when infested by the two insects under laboratory conditions.

Glass jars, each contained $10 \mathrm{~g}$ of cowpea seeds and five replicates were done for each insect and for each method and covered with perforated lids to allow its aeration, and a maximum of 3 days were allowed for mating and oviposition. Each jar was infested by five pairs for 5 five days. The parent insects were removed afterwards and the infested seeds were transferred into the replicate jars and covered with pieces of muslin cloth and fastened with rubbers to prevent the adults escape (Nonfree choice method). The jars re-incubated again at $28 \pm 1^{\circ} \mathrm{C}, 60 \pm 5 \%$ R.H. After two weeks, jars were examined for eggs count, date of the first adult emergence, progeny number, weight loss (\%) and susceptibility index (SI). The latter was calculated 
according to Dobie formula (1974) as follows:-

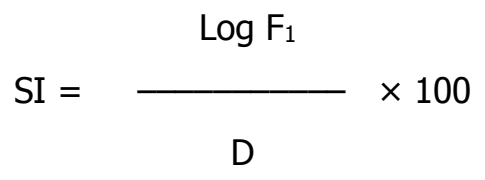

Whereas: $F_{1}=$ Total number of emerged adults and $D=$ mean developmental period (MDP, in days). The obtained values of susceptibility index (SI) were categorized into five ranks according to Mensah (1986) as follows:

A: SI values between $0.0-2.5$, were considered resistant $(R)$.

B: Those between 2.6- 5.0 were considered moderately resistant (MR).

C: SI values between 5.1- 7.5 were considered moderately susceptible (MS).

D: Values between (7.6-10.0) were susceptible (S).

E: Those $>10.0$ were considered highly susceptible (HS).

\subsection{Free - choice method:-}

Twenty seeds of each variety were identified by a marker spots, then mixed together into small Petri dish, of $15.0 \mathrm{~cm}$ diameter and then infested by five pairs adults of either $C$. maculatus and $C$. chinensis separately for five days and then removed from all Petri dishes. After two weeks, the seed varieties were separated again and seeds of each variety was placed into small glass jars of 5-7 cm diameter and covered well with muslin cloth, tightened and fastened with rubber bands then incubated at $28 \pm 1^{\circ} \mathrm{C}$ and $60 \pm 5 \%$ R.H. After 3 weeks, the jars were examined daily to record the same aforementioned biological parameters as the total eggs number, the duration of development (MPD), the progeny number, the susceptibility index and weight loss (\%), damage seeds (\%) and seeds germination (\%).

Estimation of weight loss (\%) was done by two methods. The first one was by a random selection of one hundred seeds from all replicates of each variety in case of non- free choice method; while in case of free choice method random selection of a thirty seeds was used. After being mixed together into a jar, seeds were examined for counting the damaged seeds (seeds with exit holes), weighed and numbers of undamaged seeds were also counted and weighed. Weight loss was calculated by the count and weight method mentioned by Gwinner et al., (1996) as follows: -

$$
\text { Weight loss (\%) }=\frac{\left(W_{u} \times N_{d}\right)-\left(W_{d} \times N_{u}\right)}{W_{u}\left(N_{d}+N_{u}\right)} \times 100
$$

where: $W_{u}=$ Weight of undamaged seeds $(\mathrm{gm}), \mathrm{N}_{\mathrm{u}}=$ Number of undamaged seeds, $W_{d}=$ Weight of damaged seeds $(\mathrm{gm})$ and $N_{d}=$ Number of damaged seeds. 
The second methods for calculating the weight loss was done by the method described by Rashed et al., (1996) as follow:-

$$
\text { Weight loss }(\%)=\frac{\text { Initial weight- final weight }}{\text { Initial weight }} \times 100
$$

The germination capability of both infested and sound cowpea seeds was also tested at the end of the previous experiments. Four replicates of each variety, each of 20 seeds and were planted in 9-cm diameter Petri dishes containing moistened cotton pads. After one week, number of the germinated seeds was recorded and the germination (\%) was calculated.

$$
\text { Germination }(\%)=\frac{\text { No. of germinated seeds }}{\text { Total seed number }} \times 100
$$

\section{Physical characteristics of the tested cowpea seeds:-}

\subsection{Hilux and seed texture:-}

Hilux color and the whole color of the different grain varieties were determined by visual examination of mature intact seeds. The external surface of the tested maize grains was examined, whether it is smooth, rough, or wrinkled as described by Khare and Johari (1984).

\subsection{Hunderd seeds weight (gm):-}

Three replicates of one hundred seeds of each variety were weighed on an analytical electronic balance. The mean grain weight $(\mathrm{g})$ of each variety was calculated.

\section{Chemical characteristics of the tested cowpea seeds:-}

\section{Determination of total phenols}

A ground seed sample of each replicate (3 replicates for each treatment) was washed with $\mathrm{H}_{2} \mathrm{O}$ and placed within an oven and left to dry at $45{ }^{\circ} \mathrm{C}$ for four days. Extraction was performed as according to method of Kahkonen et al., (1999). Grounded seeds (5gm) were extracted with $80 \%$ aqueous methanol with using electric homogenizer for minute. Samples were centrifuged for $10 \mathrm{~min}$ at 3000 r.p.m) and the extracts then poured into pre-weighted small conical flasks. Methanol was removed under reduced pressure. The residue (crude extract) was weighted and dissolved in $\mathrm{H}_{2} \mathrm{O}$ and to and completed a $5 \mathrm{ml}$ volume. The amount of total phenol was determined by Folin- Ciocateu method as modified by Singelton and Dossi (1965). Gallic acid standard ( $5 \%$ ) was used, and the total phenolic content was expressed as $\mathrm{mg}$ gallic acid per gm dry weight of the original sample ( $\mathrm{mg} \mathrm{GA} / \mathrm{g} \mathrm{dw}$ ).

5.2. Determination of Tannins: A ground sample from each was washed with $\mathrm{H}_{2} \mathrm{O}$ and placed in an oven to dry at $45^{\circ} \mathrm{C}$ for 4 days. A weight of $0.5 \mathrm{gm}$ was transferred to a $250 \mathrm{ml}$ conical flask. Add $75 \mathrm{ml}$ of distilled water. Heat the flask gently, boil for 30 
minutes. Centrifuge for $20 \mathrm{~min}$ at $2000 \mathrm{rpm}$ and collect the supernatant for tannins determination (Sadasivam anf Manickam, 1991). The amount of Tannins was determined by Folin- Ciocateu method as modified by as previously described.

\subsection{Estimation of total carbohydrates (\%):-}

Total carbohydrates were estimated in the acid extract of the sample by the phenol-sulphuric acid reaction of Dubois et al., (1956). Total carbohydrates was extracted and prepared for assessment according to Crompton and Birt (1967). Control was prepared by substituting distilled water for the sugar solution. The absorbance of the characteristic yellow-orange color is measured at $490 \mathrm{~nm}$ against the blank. Total carbohydrates are expressed by $\mu \mathrm{g}$ glucose/gm of the fresh weight.

\subsection{Estimation of protein (\%):-}

Total protein content was by (Bradford (1976) method. Protein reagent was prepared by $100 \mathrm{mg}$ of Coomasie Brilliant blue G-250 in $50 \mathrm{ml} \mathrm{95 \%} \mathrm{ethanol} \mathrm{and} 100$ $\mathrm{ml}$ of $85 \%(\mathrm{~W} / \mathrm{V})$ phosphoric acid was added. The resulting solution was diluted to one liter. Sample solution $(50 \mu \mathrm{l})$ was used for preparing the standard curve by $50 \mu \mathrm{l}$ of serial concentrations containing 10 to $100 \mu \mathrm{g}$ cow serum albumin were pipetted into test tubes. The volume in the tube was adapted to $1 \mathrm{ml}$ with phosphate buffer ( $0.1 \mathrm{M}, \mathrm{pH} 6.6)$ and 5 millimeters protein reagent were added and mixed either inversion or vortexing. The absorbance index was measured after $2 \min$ at $595 \mathrm{~nm}$ and before $1 \mathrm{hr}$ against a blank prepared from $1 \mathrm{ml}$ of phosphate buffer $5 \mathrm{ml}$; protein reagent.

\subsection{Estimation of crude fiber (\%):-}

Fiber (\%) was determined by the method of Maynard, (1970). Oxidative hydrolytic degradation of the native cellulose and lignin occurs During the acid and subsequent alkali treatment. The obtained residue after the final filtration was weighted, incinerated, cooled and re weighed again. The weight loss gives the crude content. Dry the residue at $130{ }^{\circ} \mathrm{C}$ for $2 \mathrm{~h}$, cool and reweigh $\left(\mathrm{W}_{1}\right)$, lignite at $600{ }^{\circ} \mathrm{C}$ for $30 \mathrm{~min}$. Cool and reweigh $\left(W_{2}\right)$. Loss of weight $\left(W_{1}-W_{2}\right)$.

\subsection{Ash content (\%):-}

Ash content of seeds sample was determined according to AOAC procedure (2000). A weight of $5 \mathrm{gm}$ placed into oven. Heat at $550^{\circ} \mathrm{C}$ over night. Cool down the desiccators. Weight the ash when the ash when the sample turns to gray:

$$
\text { Ash }(\%)=\frac{\text { Weight of ash }}{\text { Weight of sample }} \times 100
$$

\section{Statistical analysis}

The obtained data were analyzed using statistically a computer program named SAS (Proc ANOVA SAS Institute, 1998). 


\section{RESULTS}

The results of non free- choice experiment showed that all varieties were susceptible to infestation by $C$. maculatus. (Table 1 ). Significant differences among the varieties in respect to the previous parameters except (MDP) days. Eggs number was higher in Dokki331 (244.0 eggs) while the lowest was recorded in Cream7 (113.0 eggs). Progeny number of $C$. maculatus was low in Kafr El- Sheikh (85.0 adults) and Cream7 (99.0 adults) while the highest progeny were in Dokki331 and Tiba (122.0 and 118.0 adults, respectively. Mean developmental period (MDP) ranged from 20.0 to 21.0 on all cowpea varieties. The calculated susceptibility index (SI) value was 9.1 in Kafr El- Sheikh, whereas in Dokki331, SI was 11.3. The percentage of direct weight loss (DWL) \% in Cream7 reached $13.0 \%$; while on Dokki 331 reached $26.4 \%$. Undirect weight loss (UDWL) \% reached 13.6 and 12.5 on Tiba and Dokki331 respectively, while, it was 5.5 in Kaha1. Seeds damage (\%) was ranged from 76.0$84.2 \%$ on Kafr El- Sheikh and Dokki331 respectively.

Table 1. Susceptibility of some cowpea seed varieties to infestation by Callosobruchus maculatus (F.) under non- free choice method.

\begin{tabular}{|c|c|c|c|c|c|c|c|}
\hline $\begin{array}{l}\text { Cowpea } \\
\text { variety }\end{array}$ & $\begin{array}{l}\text { Mean } \\
\text { eggs } \\
\text { No. }\end{array}$ & $\begin{array}{c}\text { Progeny } \\
\text { No. }\end{array}$ & $\begin{array}{l}\text { MDP } \\
\text { (day) }\end{array}$ & $\begin{array}{c}\text { Susceptibility } \\
\text { Index (SI) }\end{array}$ & $\begin{array}{l}\text { DWL } \\
(\%)\end{array}$ & $\begin{array}{c}\text { UDWL } \\
(\%)\end{array}$ & $\begin{array}{c}\text { Seed } \\
\text { Damage } \\
(\%)\end{array}$ \\
\hline Dokki331 & $244.0 \pm 13.7 \mathrm{a}$ & $122.0 \pm 12.3 a$ & $20.0 \pm 0.5 a$ & $11.3 \pm 0.6 \mathrm{a}(\mathrm{HS})$ & $26.4 \pm 2.3 a$ & $12.5 \pm 0.3 a$ & $84.2 \pm 2.1 a$ \\
\hline Tiba & $142.0 \pm 2.7 b$ & $118.0 \pm 3.5 \mathrm{ab}$ & $19.7 \pm 1.2 \mathrm{a}$ & $10.5 \pm 0.2 b(\mathrm{HS})$ & $17.7 \pm 0.7 b$ & $13.6 \pm 1.3 a$ & $80.0 \pm 0.7 a b$ \\
\hline Kaha1 & $129.0 \pm 14.6 b$ & $110.0 \pm 10.5 a b$ & $21.0 \pm 0.0 \mathrm{a}$ & $9.7 \pm 0.1 b c(S)$ & $17.4 \pm 2.9 b$ & $5.5 \pm 0.4 c$ & $81.0 \pm 1.4 a$ \\
\hline $\begin{array}{c}\text { Kafr } \\
\text { El- Sheikh }\end{array}$ & $114.0 \pm 9.3 b$ & $85.0 \pm 14.5 b$ & $21.0 \pm 0.0 \mathrm{a}$ & $9.1 \pm 0.3 c(S)$ & $13.6 \pm 1.8 b$ & $8.2 \pm 0.9 b c$ & $75.2 \pm 1.5 b$ \\
\hline Cream7 & $113.0 \pm 3.6 b$ & $99.0 \pm 2.7 b$ & $21.0 \pm 0.0 \mathrm{a}$ & $9.5 \pm 0.4 b c(S)$ & $13.0 \pm 0.8 b$ & $11.3 \pm 1.7 a b$ & $76.0 \pm 1.4 a b$ \\
\hline $\begin{array}{c}\text { LSD } \\
(0.05 \%)\end{array}$ & 43.3 & 34.2 & - & 0.6 & 6.7 & 3.2 & 4.9 \\
\hline
\end{tabular}

Means with the same letter in the same column are not significantly different.

$\mathrm{LSD}=$ The least significant difference, $M S=$ Moderately susceptible, $M R=$ Moderately resistant, $S={ }^{*}$ Susceptible. $\mathrm{DWL}=$ Direct weight loss, UDWL= Undirect weight loss.

Data in Table (2) showed that Dokki331 variety was preferred for ovipostition (50.0) other than the rest varieties while Kaha1 variety was not preferred for oviposition (10.0 eggs). The progeny number was the lowest (8.0 adults) in Kaha1, while, it was 40.3 adults in Dokki331 variety. MDP ranged from 19.0-20.0 days in all varieties with no significant differences. The SI value was 8.4 in Dokki331 (susceptible), while it reached 4.2 in Kaha1 and considered moderately resistant (MR). Direct weight loss (DWL) (\%) was the lowest $(1.1 \%)$ in Kaha1, while it reached 6.3 (\%) in Dokii331variety. Undirect weight loss (UDWL) (\%) was the highest (14.4) in 
Tiba, and the lowest in Kaha1 which reached $2.3 \%$. Damage seeds (\%) reached 62.5 and $25.0 \%$ on Dokki331 and Kaha1 respectively. The results indicated that two cowpea varieties named Cream7 and Kafr El- Sheikh were moderately susceptible (MS), two susceptible (S) Dokki331 and Tiba except Kaha1 was moderately resistant (MR) to C. maculatus in free- choice experiments.

It was concluded from the tests of both choice and non-choice methods that Dokki331 and Tiba were susceptible to insect infestation by both insects, while Cream7 and Kafr El- Sheikh were moderately susceptible and one variety (Kaha1) was moderately resistant (MR) to C. maculatus under free- choice experiments.

Table 2. Susceptibility of some cowpea seed varieties to infestation by Callosobruchus maculatus (F.) under free choice method.

\begin{tabular}{|c|c|c|c|c|c|c|c|}
\hline $\begin{array}{l}\text { Cowpea } \\
\text { variety }\end{array}$ & $\begin{array}{l}\text { Mean } \\
\text { eggs } \\
\text { No. }\end{array}$ & $\begin{array}{l}\text { Mean } \\
\text { Progeny } \\
\text { No. }\end{array}$ & $\begin{array}{l}\text { MDP } \\
\text { (day) }\end{array}$ & $\begin{array}{c}\text { Susceptibility } \\
\text { Index (SI) }\end{array}$ & $\begin{array}{l}\text { DWL } \\
(\%)\end{array}$ & $\begin{array}{c}\text { UDWL } \\
(\%)\end{array}$ & $\begin{array}{c}\text { Seed } \\
\text { Damage } \\
(\%)\end{array}$ \\
\hline Dokki331 & $50.0 \pm 12.4 a$ & $40.3 \pm 6.7 a$ & $19.0 \pm 0.5 a$ & $8.4 \pm 0.6 \mathrm{a}(\mathrm{S})$ & $6.3 \pm 0.8 a$ & $9.7 \pm 2.1 b$ & $62.5 \pm 8.7 a$ \\
\hline Tiba & $42.0 \pm 11.0 \mathrm{a}$ & $33.0 \pm 9.0 \mathrm{ab}$ & $19.2 \pm 0.7 \mathrm{a}$ & $8.1 \pm 0.3 a b(S)$ & $4.6 \pm 1.0 \mathrm{a}$ & $14.4 \pm 1.7 \mathrm{a}$ & $52.5 \pm 6.2 \mathrm{a}$ \\
\hline Kaha1 & $10.0 \pm 1.0 b$ & $8.0 \pm 1.2 b$ & $20.0 \pm 0.0 \mathrm{a}$ & $4.2 \pm 0.4 c(M R)$ & $1.1 \pm 0.0 b$ & $2.3 \pm 0.1 c$ & $25.0 \pm 3.8 b$ \\
\hline $\begin{array}{c}\text { Kafr } \\
\text { El-Sheikh }\end{array}$ & $42.8 \pm 11.7 \mathrm{a}$ & $31.4 \pm 8.6 \mathrm{a}$ & $19.8 \pm 0.0 \mathrm{a}$ & $7.4 \pm 0.5 a b(M S)$ & $5.1 \pm 2.1 \mathrm{a}$ & $11.5 \pm 2.0 a b$ & $59.0 \pm 8.7 a$ \\
\hline Cream7 & $34.2 \pm 6.5 \mathrm{ab}$ & $23.0 \pm 4.2 a$ & $20.0 \pm 0.4 a$ & $6.6 \pm 0.6 b(\mathrm{MS})$ & $4.1 \pm 1.1 \mathrm{ab}$ & $7.5 \pm 0.8 b$ & $54.0 \pm 11.6 a$ \\
\hline $\begin{array}{c}\text { LSD } \\
(0.05 \%)\end{array}$ & 26.2 & 19.1 & - & 1.6 & 3.2 & 4.8 & 25.8 \\
\hline
\end{tabular}

Means with the same letter in the same column are not significantly different.

$\mathrm{LSD}=$ The least significant difference, $M S=$ Moderately susceptible, $M R=$ Moderately resistant, $S={ }^{*}$ Susceptible.

Table (3) showed significant differences among the studied parameters except directed weight loss (DWL) (\%). Mean eggs number was 81.0 in Dokki331 variety and in Kaha1 was 26.0 eggs. Lowest progeny number was 16.0 adults in Kaha1, while, it was 67.0 adults in Dokki331. MDP (days) was the same in all varieties. The values of SI of tested varieties was (9.7) in Dokki331 and the lowest was 5.9 in Kaha1 and considered moderately susceptible (MS). The percentage of direct weight loss (DWL) \% was $3.3 \%$ in Kaha1 while it reached $12.9 \%$ on Dokki331. Undirect weight loss (UDWL) \% was $6.3 \%$ in Dokki331 while it reached $1.3 \%$ on Kaha1. Damage seed (\%) was the highest in Dokki 331 (71.9\%) and the lowest was in Cream7 variety to (19.1\%).

The results of non-free- choice experiments of $C$. chinensis on cowpea varieties indicated that three varieties were susceptible and two varieties were moderately susceptible (Table 3). 
Table 3. Susceptibility of some cowpea seed varieties to infestation by Callosobruchus chinensis (L.) under non- free choice method.

\begin{tabular}{|c|c|c|c|c|c|c|c|}
\hline $\begin{array}{c}\text { Cowpea } \\
\text { variety }\end{array}$ & $\begin{array}{c}\text { Mean } \\
\text { eggs } \\
\text { No. }\end{array}$ & $\begin{array}{c}\text { Progeny } \\
\text { No. }\end{array}$ & $\begin{array}{c}\text { MDP } \\
\text { (day) }\end{array}$ & $\begin{array}{c}\text { Susceptibility } \\
\text { Index (SI) }\end{array}$ & $\begin{array}{c}\text { DWL } \\
(\%)\end{array}$ & $\begin{array}{c}\text { UDWL } \\
(\%)\end{array}$ & $\begin{array}{c}\text { Seed } \\
\text { Damage } \\
(\%)\end{array}$ \\
\hline Dokki331 & $81.0 \pm 9.5 \mathrm{a}$ & $67.0 \pm 15.2 \mathrm{a}$ & $19.0 \pm 0.0 \mathrm{~b}$ & $9.7 \pm 0.5 \mathrm{a}(\mathrm{S})$ & $12.9 \pm 1.2 \mathrm{a}$ & $6.3 \pm 1.2 \mathrm{a}$ & $71.9 \pm 0.7 \mathrm{a}$ \\
\hline Tiba & $50.0 \pm 7.4 \mathrm{bc}$ & $34.0 \pm 4.2 \mathrm{ab}$ & $19.0 \pm 0.0 \mathrm{~b}$ & $8.0 \pm 0.3 \mathrm{ab}$ (S) & $6.5 \pm 0.3 \mathrm{~b}$ & $4.4 \pm 1.1 \mathrm{ab}$ & $36.6 \pm 3.0 \mathrm{bc}$ \\
\hline Kaha1 & $26.0 \pm 1.3 \mathrm{c}$ & $16.0 \pm 6.8 \mathrm{~b}$ & $20.0 \pm 0.0 \mathrm{ab}$ & $5.9 \pm 0.6 \mathrm{c}$ (MS) & $3.1 \pm 0.6 \mathrm{~b}$ & $1.3 \pm 0.2 \mathrm{~b}$ & $19.1 \pm 3.1 \mathrm{c}$ \\
\hline $\begin{array}{c}\text { Kafr } \\
\text { El-Sheikh }\end{array}$ & $57.2 \pm 13.3 \mathrm{ab}$ & $47.2 \pm 10.7 \mathrm{ab}$ & $20.0 \pm 0.2 \mathrm{ab}$ & $8.1 \pm 0.8 \mathrm{ab}$ (S) & $6.2 \pm 2.1 \mathrm{~b}$ & $6.2 \pm 1.0 \mathrm{a}$ & $53.8 \pm 12.9 \mathrm{ab}$ \\
\hline Cream7 & $46.3 \pm 8.1 \mathrm{ac}$ & $31.0 \pm 8.1 \mathrm{~b}$ & $21.0 \pm 0.5 \mathrm{a}$ & $6.9 \pm 0.6 \mathrm{bc}$ (MS) & $4.9 \pm 2.8 \mathrm{~b}$ & $4.9 \pm 1.1 \mathrm{ab}$ & $25.1 \pm 5.1 \mathrm{bc}$ \\
\hline $\begin{array}{c}\text { LSD } \\
\text { (0.05\%) }\end{array}$ & 28.7 & 31.5 & 1.2 & 1.7 & 4.0 & 3.5 & 30.1 \\
\hline
\end{tabular}

Means with the same letter in the same column are not significantly different.

$\mathrm{LSD}=$ The least significant difference, $M S=$ Moderately susceptible, $M R=$ Moderately resistant, $\mathrm{S}={ }^{\text {* }}$ Susceptible.

Data in Table (4) showed significant differences among the tested varieties in mean number of eggs, susceptibility index, progeny number, and weight loss (DWL) (\%) and damage seeds (\%). Mean eggs number on Dokki331 was (44.4 eggs) while, in Kaha1 was 14.3 eggs. Lowest progeny number was in Kaha1 and Cream7 (9.0 and 10.0 adults) respectively, while Tiba variety harboured the highest progeny number (33.0 adults). The MDP (days) was the same in all varieties. The highest SI value was 7.8 in Tiba, while, it was the lowest (4.2) on both Kaha1 and Cream7. The percentage of direct weight loss (DWL) (\%) was higher $12.7 \%$ in Tiba while it reached $5.5 \%$ in Kaha1. Undirect weight loss (UDWL) (\%) was 7.8 in Cream7 while, it reached to 16.7 $\%$ in Tiba. Damaged seed (\%) was high in Tiba (68.3), while it was low (36.2 and 36.6). on Cream7 and Kaha1, respectively.

The results in table (4) indicated that two varieties (Tiba and Dokki331) were susceptible (S), one variety (Kafr El- Sheikh) moderately susceptible (MS) and two varieties (Kaha1 and Cream7) were moderately resistant (MR). 
Table 4. Susceptibility of some cowpea seed varieties infested by to $C$. chinensis under free- choice method.

\begin{tabular}{|c|c|c|c|c|c|c|c|}
\hline $\begin{array}{c}\text { Cowpea } \\
\text { variety }\end{array}$ & $\begin{array}{c}\text { Mean } \\
\text { eggs } \\
\text { No. }\end{array}$ & $\begin{array}{c}\text { Progeny } \\
\text { No. }\end{array}$ & $\begin{array}{c}\text { MDP } \\
\text { (day) }\end{array}$ & $\begin{array}{c}\text { Susceptibility } \\
\text { Index (SI) }\end{array}$ & $\begin{array}{c}\text { DWL } \\
(\%)\end{array}$ & $\begin{array}{c}\text { UDWL } \\
(\%)\end{array}$ & $\begin{array}{c}\text { Seed } \\
\text { Damage } \\
(\%)\end{array}$ \\
\hline Dokki331 & $44.0 \pm 10.1 \mathrm{a}$ & $26.0 \pm 4.4 \mathrm{ab}$ & $19.0 \pm 0.9 \mathrm{a}$ & $7.2 \pm 0.5 \mathrm{ab}$ (S) & $10.5 \pm 1.5 \mathrm{ab}$ & $14.4 \pm 2.2 \mathrm{a}$ & $50.0 \pm 7.6 \mathrm{ab}$ \\
\hline Tiba & $37.0 \pm 4.9 \mathrm{ab}$ & $33.0 \pm 0.7 \mathrm{a}$ & $19.3 \pm 0.3 \mathrm{a}$ & $7.8 \pm 0.1 \mathrm{a}$ (S) & $12.7 \pm 0.8 \mathrm{a}$ & $16.7 \pm 2.1 \mathrm{a}$ & $68.3 \pm 3.5 \mathrm{a}$ \\
\hline Kaha1 & $14.3 \pm 5.3 \mathrm{~b}$ & $9.0 \pm 4.2 \mathrm{c}$ & $20.0 \pm 0.0 \mathrm{a}$ & $4.2 \pm 0.9 \mathrm{~b}$ (MR) & $5.5 \pm 1.2 \mathrm{~b}$ & $13.6 \pm 1.4 \mathrm{a}$ & $36.6 \pm 3.5 \mathrm{~b}$ \\
\hline $\begin{array}{c}\text { Kafr } \\
\text { El-Sheikh }\end{array}$ & $24.0 \pm 2.2 \mathrm{~b}$ & $19.5 \pm 2.5 \mathrm{bc}$ & $20.5 \pm 0.7 \mathrm{a}$ & $6.2 \pm 0.2 \mathrm{ab}$ (MS) & $9.1 \pm 1.0 \mathrm{ab}$ & $13.3 \pm 2.1 \mathrm{a}$ & $52.0 \pm 16.2 \mathrm{ab}$ \\
\hline \begin{tabular}{c} 
Cream7 \\
\hline $\begin{array}{c}\text { LSD } \\
(0.05 \%)\end{array}$
\end{tabular} & $13.6 \pm 3.4 b$ & $10.0 \pm 3.5 \mathrm{c}$ & $20.8 \pm 1.4 \mathrm{a}$ & $4.2 \pm 1.4 \mathrm{~b}$ (MR) & $5.7 \pm 2.1 \mathrm{~b}$ & $7.8 \pm 2.6 \mathrm{a}$ & $36.2 \pm 9.4 \mathrm{~b}$ \\
\hline
\end{tabular}

Means with the same letter in the same column are not significantly different.

$\mathrm{LSD}=$ The least significant difference, $\mathrm{MS}=$ Moderately susceptible, $\mathrm{MR}=$ Moderately resistant, $\mathrm{S}=$ *

Susceptible.

Data in Table (5) revealed that the germination percentage of cowpea varieties after infestion by $C$. maculatus under non- free choice method were $50 \%$ and 71.2 in Dokki331 and Cream7 compared to the control which recorded $93.7 \%$ and $100 \%$, respectively, whereas, in free- choice method germination percentage were $55.0 \%$ and $81.2 \%$ in Dokki331 and Kaha1 varieties compared to control (93.7 and $100 \%$ ) respectively, on the other hand the highest germination percentage of cowpea treated varieties infested by $C$. chinensis was $92.5 \%$ in Tiba variety, while the lowest was $71.2 \%$ recorded in Kaha1 in non free choice method, while in free choice method the highest germination percentage was $95 \%$ in Tiba and the lowest was $67.5 \%$ in Dokki331 while the control recorded the complete germination percentage (100\%) compared to treated varieties.

Table 5. Germination percentage of some cowpea seed varieties infested by C. maculatus and $C$. chinensis .

\begin{tabular}{|c|c|c|c|c|c|}
\hline \multirow{2}{*}{$\begin{array}{l}\text { Cowpea } \\
\text { varieties }\end{array}$} & \multicolumn{2}{|c|}{ C. maculatus } & \multicolumn{2}{|c|}{ C. chinensis } & \multirow{2}{*}{ Control } \\
\hline & $\begin{array}{c}\text { Non - free } \\
\text { choice } \\
\text { test }\end{array}$ & $\begin{array}{c}\text { Free choice } \\
\text { test }\end{array}$ & $\begin{array}{c}\text { Non - free } \\
\text { choice } \\
\text { test }\end{array}$ & $\begin{array}{c}\text { Free choice } \\
\text { test }\end{array}$ & \\
\hline Dokki331 & $50.0 \pm 2.0 b$ & $55.0 \pm 1.4 b$ & $65.0 \pm 5.2 b$ & $67.5 \pm 6.7 c$ & $93.7 \pm 3.1 a$ \\
\hline Tiba & $61.2 \pm 4.2 a b$ & $65.0 \pm 2.8 b$ & $92.5 \pm 1.4 a$ & $95.0 \pm 3.8 a$ & $100.0 \pm 0.0 \mathrm{a}$ \\
\hline Kaha1 & $63.7 \pm 4.2 a b$ & $81.2 \pm 5.2 a$ & $71.2 \pm 2.5 b$ & $86.2 \pm 2.5 a b$ & $100.0 \pm 0.0 \mathrm{a}$ \\
\hline $\begin{array}{c}\text { Kafr } \\
\text { El-Sheikh }\end{array}$ & $70.0 \pm 8.4 a$ & $80.0 \pm 3.8 a$ & $75.0 \pm 5.2 b$ & $81.6 \pm 3.5 a b c$ & $96.2 \pm 3.7 a$ \\
\hline Cream7 & $71.2 \pm 3.1 a$ & $78.7 \pm 3.8 \mathrm{a}$ & $73.0 \pm 6.5 b$ & $76.6 \pm 1.7 b c$ & $100.0 \pm 0.0 \mathrm{a}$ \\
\hline $\begin{array}{c}\text { LSD } \\
(0.05 \%)\end{array}$ & 14.8 & 13.1 & 15.1 & 15.5 & - \\
\hline
\end{tabular}

Means in the same column with the same letter are not significantly different. 
Data in Table (6) indicated that the physical characteristics of the tested cowpea seeds varieties. Seeds color was creamy light in all varieties except Kafer ElSheich and Cream7 were Creamy. Seed size was large in Dokii331 and Tiba while small in Kafer El-Sheich and Cream7. Hilux color was brown in all varieties except it was black on Dokii331.Seeds shape was Kidney in all varieties except Kafer El-Sheich and Cream 7 was barrel. Mean weight of one hundred seeds in Dokki 331 and Tiba were 21.5 and $20.3 \mathrm{gm}$ respectively while was 13.3 on in Kaha1.

Table 6. Physical characters of the seeds of some cowpea varieties.

\begin{tabular}{|c|c|c|c|c|c|}
\hline $\begin{array}{c}\text { Cowpea } \\
\text { variety }\end{array}$ & Seed color & Seed size & $\begin{array}{c}\text { Hilux } \\
\text { color }\end{array}$ & $\begin{array}{c}\text { Seeds } \\
\text { shape }\end{array}$ & $\begin{array}{c}\text { Mean weight of } \\
\text { one hundred seed } \\
(\mathrm{gm})\end{array}$ \\
\hline Dokki331 & Creamy light & Large & black & Kidney & $21.5 \pm 0.3 \mathrm{a}$ \\
\hline Tiba & Creamy light & Large & brown & Kidney & $20.3 \pm 0.5 \mathrm{a}$ \\
\hline Kaha1 & Creamy light & Medium & brown & Kidney & $13.3 \pm 0.3 \mathrm{c}$ \\
\hline Kafr El- Sheikh & Creamy & Small & brown & barrel & $14.4 \pm 0.7 \mathrm{~b}$ \\
\hline Cream7 & Creamy & Small & brown & barrel & $10.5 \pm 0.1 \mathrm{~d}$ \\
\hline $\begin{array}{c}\text { LSD } \\
(0.05)\end{array}$ & - & - & - & - & 0.7 \\
\hline
\end{tabular}

Data in Table (7) showed chemical components of the selected cowpea varieties as total proteins, total phenols, tannins, total carbohydrates, crude fiber and ash \%). The results showed that the highest total protein $(\mathrm{mg} / \mathrm{g})$ recorded in Tiba (289.3 $\mathrm{mg} / \mathrm{g}$ ) and the lowest was $257.3 \mathrm{mg} / \mathrm{g}$ in Kafr El-Sheikh with a significant difference. Total phenols $(\mathrm{mg} / \mathrm{g})$ showed no significant in the tested varieties, whereas, the tannins showed a significant difference in the tested varieties and the highest recorded in Cream7 variety $(224.0 \mathrm{mg} / \mathrm{g}$ ) and the lowest amounts 190.0 $(\mathrm{mg} / \mathrm{g})$ and 195.0 was recorded in Dokki331 and Tiba variety. Total carbohydrates $(\mathrm{mg} / \mathrm{g})$ were 335.0 and $229.0(\mathrm{mg} / \mathrm{g})$ in Cream7 and Tiba varieties, respectively with significant difference the highest. Cured fiber $(\mathrm{mg} / \mathrm{g})$ content was $8.3 \mathrm{mg} / \mathrm{g}$ in Kafr ElSheikh and the lowest $(5.3 \mathrm{mg} / \mathrm{g}$ ) were recorded in Tiba, respectively whereas in ash $\%$ the values were 1.7 and 1.4 in Tiba and Cream7. From the results it was clear that the susceptible varieties showed a higher content of total proteins and ash\%, while the moderately susceptible varieties showed higher contents of tannins, total carbohydrates and crude fiber. 
Table 7. Chemical components of some selected cowpea seed varieties.

\begin{tabular}{|c|c|c|c|c|c|c|}
\hline $\begin{array}{c}\text { Test } \\
\text { varities }\end{array}$ & $\begin{array}{c}\text { Total } \\
\text { Proteins } \\
(\mathrm{mg} / \mathrm{g})\end{array}$ & $\begin{array}{c}\text { Total } \\
\text { Phenols } \\
(\mathrm{mg} / \mathrm{g})\end{array}$ & $\begin{array}{c}\text { Tannins } \\
(\mathrm{mg} / \mathrm{g})\end{array}$ & $\begin{array}{c}\text { Total } \\
\text { Carbohydrates } \\
(\mathrm{mg} / \mathrm{g})\end{array}$ & $\begin{array}{c}\text { Crude } \\
\text { Fiber } \\
(\mathrm{mg} / \mathrm{g})\end{array}$ & $\begin{array}{c}\text { Ash } \\
(\%)\end{array}$ \\
\hline Dokki331 & $289.0 \pm 2.3 \mathrm{a}$ & $1.8 \pm 0.0 \mathrm{a}$ & $190.0 \pm 1.2 \mathrm{c}$ & $244.0 \pm 6.1 \mathrm{c}$ & $7.3 \pm 0.1 \mathrm{~b}$ & $1.6 \pm 0.0 \mathrm{ab}$ \\
\hline Tiba & $289.3 \pm 2.5 \mathrm{a}$ & $1.9 \pm 0.0 \mathrm{a}$ & $195.0 \pm 2.5 \mathrm{c}$ & $229.0 \pm 4.1 \mathrm{c}$ & $5.3 \pm 0.0 \mathrm{c}$ & $1.7 \pm 0.2 \mathrm{a}$ \\
\hline $\begin{array}{c}\text { Kafr } \\
\text { El-Sheikh }\end{array}$ & $257.3 \pm 1.8 \mathrm{c}$ & $2.0 \pm 0.0 \mathrm{a}$ & $205.0 \pm 2.6 \mathrm{~b}$ & $280.0 \pm 4.6 \mathrm{~b}$ & $8.3 \pm 0.1 \mathrm{a}$ & $1.5 \pm 0.0 \mathrm{~b}$ \\
\hline Cream7 & $276.6 \pm 1.0 \mathrm{~b}$ & $2.0 \pm 0.0 \mathrm{a}$ & $224.0 \pm 1.0 \mathrm{a}$ & $335.0 \pm 5.0 \mathrm{a}$ & $7.7 \pm 0.1 \mathrm{~b}$ & $1.4 \pm 0.0 \mathrm{~b}$ \\
\hline LSD & 7.2 & - & 7.5 & 18.8 & 0.4 & 0.2 \\
$(0.05 \%)$ & & & & & & \\
\hline
\end{tabular}

\section{DISCUSSION}

The genotype suitability for insect development is determined on the basis of susceptibility index (SI) values. This parameter is used for comparing the insect growth responses to different crop varieties (Howe, 1971). Genotypes or varieties with low SI are considered resistant $(\mathrm{R})$ and those with a high SI values are considerable susceptible (S).

The food preference of the two pests on tested cowpea varieties under free and non- free-choice methods showed that oviposition preference, adult's survival, duration of development, susceptibility index and weight loss are depending on insect type, cowpea variety and the method of infestation. The present results agree with those reported by (Chijindu et al., 2009) mentioned that the ovipositional preference and survival of $C$. maculatus on cowpea are depending on physical factors as seed texture and size. The seeds with smooth seed surface make cowpeas more preferred for eggs laying, percent weight loss and percent adult survival. They mentioned that the soft seed texture permit the easy penetration of they larvae compared to the rough one.

The tested cowpea varieties in the present study have smooth surface texture and with various size differences (Table 6). Larger seed size might have encouraged the adults to lay more eggs and much development (Lephale et al., 2012).

The protein content was high in the susceptible varieties. Other chemical factors as trypsin inhibitors and variant vicilins (storage globulins) are responsible for seed resistance since it cause antibiosis in the larvae (Chijindu et al., 2009). Other workers explained the variation in cowpea varieties infested by bruchids to genetic factors and presence of biochemical components as the tannin content, trypsin inhibitors and phenol content (Deshpande et al., 2011) and these results agree with many researchers working on different cowpea varieties (Bhatnagar et al., 2011). The biochemical attributes constitute an important role for resistance against cowpea bruchid. Total carbohydrates and - amylase inhibitory activity of the seeds were associated with resistance to bruchids and the other chemical compounds as protein, 
tannins, flavonoids and phenolic compounds were not associated with seed resistance (Belay et al., 2017). The later workers found the resistant cowpea have low tannins content while the susceptible cowpea variety showed high content. The total carbohydrate content is higher in the resistant cowpea genotypes compared with those of susceptible ones and it cause an increase of seed hardness (Ajeigbe et al., 2008) therby making seed penetration by the insect larvae difficult in addition to offering barrier. The evaluated level of - amylase inhibitory activity in the cotyledons of cowpea genotypes is responsible for resistance to C. maculatus (Belay et al., 2017) since this enzyme inhibit the enzymes responsible for starch digestion and so prolong the insect growth developmental beside reducing the levels of the adult emergence.

The present results demonstrated that Dokki 331 (with larger seed size) is more susceptible than the smaller sized seeds as Cream7 and Kaha1.These findings should put in our consideration in local cowpea breeding for producing other newer varieties. The cowpea varieties with smooth texture seeds coats attracted more oviposition and supported the highest number of laid eggs by $C$. maculatus. This information could guide breeders on how to improve in cowpea varieties by focusing on elevating the level of seed - amylase inhibitory and carbohydrate content. All the tested cowpea varieties exhibit various degrees of resistance when infested with both insects ( $C$. maculatus and $C$. chinensis) under free and non free-choice methods. From this study Cream7 and Kaha1 were more resistant varieties to $C$. maculatus and $C$. chinensis attack of the studied parameters (SI, adult emergence, weight loss (\%) and damage (\%). This study suggests that the cowpea varieties could not be stored without other complementary control means for reducing damage and weight loss by bruchids attack.

\section{REFERENCES}

1. Ajeigbe H. A.; D. Ihedioha and D. Chikoye. 2008. Variation in physico-chemical properties of seed of selected improved varieties of cowpea as it relates to industrial utilization of the crop. African Journal of Biotechnology, 7, 3642-3647.

2. Augustine, A. M.; J. E. doko and A. O. Adepoju. 2016. Ovipositional response of seed beetle Callosobruchus maculatus (F.) (Coleoptra: Chrysomelidae) on some selected varieties of cowpea, Vigna unguiculata (L.) Walp. International Journal of Research in Agriculture and Forestry, 3 (5): 28-34.

3. A. O. A. C., 2000. Association of the official Agriculture chemists. Washington, D.C., U. S. A.

4. Belay, M.; M. Ulemu; H. Mehari; M. Geoffrey; O. Thomas; E. Richard; G. Paul ; R. Patrick and K. Samuel. 2017. Biochemical basis of cowpea resistance to 
bruchid Callosobruchus maculatus (F.). International Journal of research, 5 (10):219-227.

5. Bhatnagar, A.; N. S. Bhadauria and S. S. Jakhmola. 2011. Efficacy of vegetable oils against pulse beetle, Callosobruchus maculatus in cowpea. Indian Journal of Entomology, 63(3): 237-239.

6. Boeke, S. J. 2004. Host preference of Callosobruchus maculatus: a comparison of life history characteristics for three strains of beetles on two varieties of cowpea. Journal of applied Entomology, 128 (6):390-396.

7. Bradford, M. M. 1976. A rapid and sensitive methods for the quantitation of microgram of proteins utilizing the principle of protein-dye binding. Analytical Biochemistry, 72:248-254.

8. Caswell, G. H. 1981. Damage to stored cowpea in the northern part of Nigeria. Samaru Journal of Agriculture Researchrecd. 1, 11-19.

9. Chakraborthy, S.; C. S. N Chaudhuri and S. K. Senapati. 2015. Evaluation of relative susceptibility of Callosobruchus chinensis Linn on five different stored pulse seeds. Asian Journal of Plant Science and resesarch, 5(10):9-15.

10. Chijindu, E. N.; N. J. Okonkwo; N. T. Umeweni and S. U. Ndidi. 2009. Susceptibility of cowpea varieties (Vigna subterranean) (L) Walp to infestation by Callosobruchus maculatus (F.) (Coleoptera: Bruchidae). Journal of Applied Sciences, 12 (1): 8368-379.

11. Crompton, M and L. M. Birt. 1967. Changes in the amounts of carbohydrates phoshagen and related compounds during the metamorphosis of the blowfly, Lucilia curprina. Journal Insect of physiology, 13:1575-1595.

12. Deshpande, V. K.; B. Makanur; S. K. Deshpande; S. Adiger and Salimath P. M. 2011. Quantitative and qualitative losses caused by Callosobruchus maculatus in cowpea during seed storage. Plant Archives 11, 723-731.

13. Dobie, P. 1974. The laboratory assessment of the inherent susceptibility. of maize varieties to post-harvest infestation by Sitophilus zeamais (Motsch.) Coleoptera: Curculionidae). Journal of Stored Product Research, 10: $183-197$.

14. Dubios, M.; K. A. Gilles; J. K.Hamilton; P. A. Rebers and F. Smith. 1956. Colorimetric method for determination of sugar and relatrd substabces. Aanlytical chemistry, 28:350-356.

15. Howe, R. W. 1971. A parameter for expressing the suitability of an environment for insect development. Journal of Stored Products Research, 7: 63-65.

16. Goutam, B. H.; S. B. Jagginavar and S. S. Karabhantanal. 2016. Host preference studies on Callosobruchus chinensis (Linnaeus) in different pulses. Journal of Entomology and Zoology Studies, 4 (6): 872-875. 
17. Gwinner, J.; R. Harnish and O. Muck. 1996. Manual on the prevention of post Harvest grain loss. GTZ, Eschborn, Germany, pages: 334.

18. Heinonen. 1999. Antioxidant acticity of plant extracts containing phenolic compounds. Journal of Agriculture and Food Chemistry, 47: 3954-3962.

19. Kahkonen, M. P.; A. I. Hopia; H. J. Vuorela; J. P. Rauha; K. Pihlaja; T. S. Kujala and $M$.

20. Khare, B. P and R. K. Johari. 1984. Influence of phenotypic characters of chickpea (Cicer arietinum, L.) cultivars on their susceptibility to Callosobruchus chinensis (L.). Legume Research, 7 (1): 54-56.

21. Lephale, S.; A. Addo-Bediako and V. Ayodele. 2012. Susceptibility of seven cowpea cultivars (Vigna unguiculatus) to cowpea beetle (Callosobruchus maculatus). Agricultural Science Research Journal. 2 (2): 65-69.

22. Maynard, A. J. 1970. Methods in food analysis. Academic Press, New York, P. 176.

23. Mensah, G. W. K. 1986. Infestation potential of Callosobruchus maculatus (F.) (Coleoptera: Bruchidae) on cowpea cultivars stored under sub- tropical conditions. Insect Sciences and Application, 7 (6): 781-784.

24. Rashed, S. S.; F. A. El-sayed and M. S. Gharib. 1996. Effect of seed density of two Egyptian varieties of mungbean seeds on the reproductive performance of Callosobruchus chinensis (L.) (Coleoptera: Bruchidae) and their susceptibility to infestation. Egyptian Journal of Agricultural Research, 74 (1):71-81.

25. Sadasivam, S and A. Manickam. 1991. Tannins in biochemical methods for agriculture sciences (Wiley eastern limited and Tamil Nadu agriculture university, Coimbtore). P. 189-190).

26. SAS Institute. 1998. SAS Institute users' guide (statistical). SAS Institute, Cay,

27. Shaheen, F. A.; A. Khaliq and M. Aslam. 2006. Resistance of chickpea (Cicer arietinum (L.) Cultivars against pulse beetle. Pakistan Journal of Botany, 38 (4): 1237-1244.

28. Singleton, V. L and J. A. Rossi. 1965. Colorimetry of total phenolics with phosphomolybdic- phosphotungstic acid reagents. Am.j. Enol.Vitic., 16:144158. 


\section{حساسية بعض أصناف اللوبيا \\ للإصابة بنوعين من خنافس البقول}

\section{عصام مصطقى محمد1- عبد الله الحسبن عبد المنعم2 2 \\ محروس سليمان غريب1'- شريف فاروق حافظ2

$$
\begin{aligned}
& \text { 1. معهُ بحوث وقاية النبتات -الدقى - جيزة مصر } \\
& \text { 2. قسم وقاية النبات- كلية الزراعة- جامعة الأزهر-القاهرة }
\end{aligned}
$$

يعتبر محصول اللوبيا من محاصيل الخضر الهامة فى مصر حيث تستخدم بذورها في تغذية

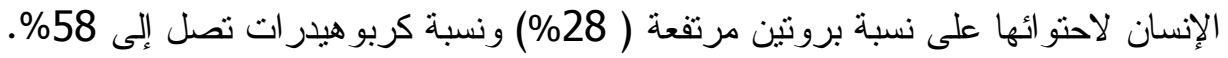

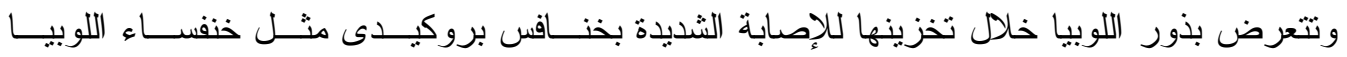
Callosobruchus maculatus وخنفساء البقول الصينية C. chinensis وتم في الدراسة الحالية تقـيم حساسية خمسة أصناف من اللوبيا هي دقى 331 وطيبة وقها 1 وكفر الثيخ وكريم 7 لمعرفه مسلدى فئس قابليتهم للإصابة بكلا الحشرتين وحساب عدد من الصفات البيولوجية كعدد البيض الكلى وفترة النمو

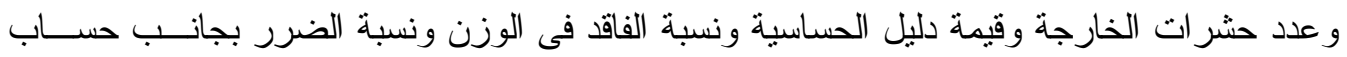

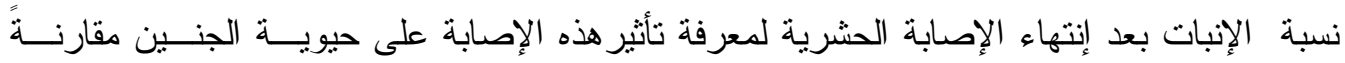

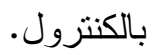

أظهرت النتائج أن جميع أصناف اللوبيا كانت حساسة للإصــابة الحشــرية وبــدرجات مختلفة وكان الصنف دقى 331 وطيبة أكثر الأصناف قابلية للإصـابة بينما كان الصــنف كفر الثــيخ

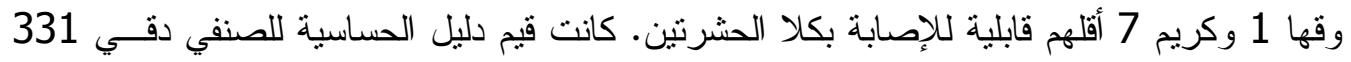

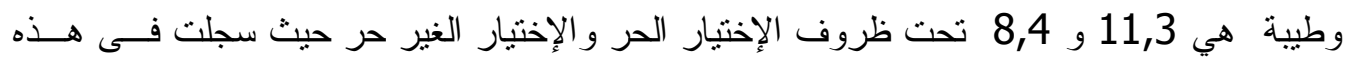
الأصناف نسبة خسائر عالية فى كل من الوزئه والون والتلف مقارنة باللأصناف الأخرى.

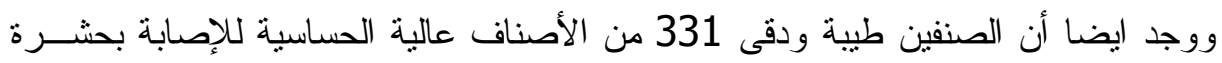

خنفساء البقول حيث كانت قيم دليل الحساسية 7,8 و 7,2 على التو الى تحت ظروف الإختيار الحر.

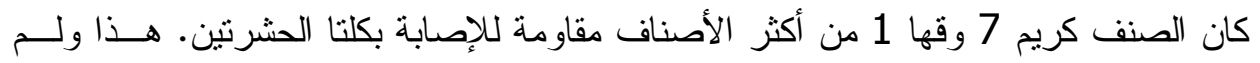

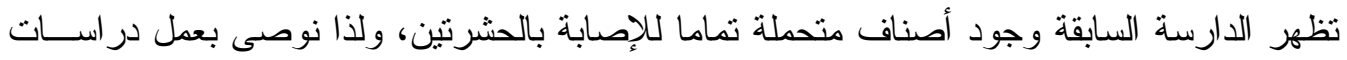
أخرى مكملة لوقاية هذه الإصناف من الإصابة بحشر ات خنافس بروكيدى. 
136 